\title{
Effects of Mandrax and Cannabis on the cellular function of chick embryonic neurons
}

\author{
A.A. da Silva ${ }^{a}$, M.J. Bester ${ }^{a}$ and E. Pretorius ${ }^{a}$ \\ ${ }^{a}$ Department of Anatomy, School of Health Sciences, BMW Building, P.O. Box 2034, \\ University of Pretoria, Pretoria 0001, South Africa
}

\section{Abstract}

Cannabis and Mandrax abuse is unique to South Africa; and most research has focused on the socio-economic impact rather than the adverse effects on the developing brain. Therefore, the aim of this study is to determine the effects of Mandrax and Cannabis alone and in combination on the developing brain by using primary and suspension cultures of the chick embryo brain.

Exposure of primary chick embryo neuronal (CEN) cultures to the carrier ethanol, Mandrax and Cannabis, for $24 \mathrm{~h}$ resulted in a significant dose dependent decrease in cell number for Mandarx alone. Increasing concentrations of Cannabis in combination with Mandrax inhibited the toxic effect of Mandrax. In CEN suspensions, Mandrax alone induced a significant time-concentration dependent decrease in esterase activity following 1 and $4 \mathrm{~h}$ exposure. In combination with Cannabis, a significant increase in esterase activity was observed after $4 \mathrm{~h}$ exposure. In conclusion Mandrax is toxic to CEN cells in vitro while Cannabis seemed to have a protective effect; however, this study does not investigate the abuse of these drugs in the form commonly abused, namely inhaled smoke. 


\section{Article Outline}

1. Introduction

2. Materials and methods

2.1. Isolation of chick embryonic neuronal (CEN) cells

2.2. Extracts of Mandrax and Cannabis

2.3. Exposure of CEN primary cultures to Mandax and Cannabis alone and combination

2.4. Crystal Violet (CV) assay

2.5. Exposure of CEN suspension cultures to Mandax and Cannabis alone and combination

2.6. Fluorescein diacetate (FDA) assay

2.7. Statistical analysis

3. Results

3.1. The effect of Mandrax and Cannabis alone or in combination on CEN cell number 3.2. Effect of Mandrax and Cannabis either alone or in combination on CEN esterase activity

4. Discussion

References

\section{Introduction}

Cannabis and Mandrax (the active ingredient Methaqualone, MTQ) are the most frequently reported illicit drugs of abuse in South Africa. Usually Cannabis and Mandrax are abused in combination (Medical Research Council, 2000: www.mrc.co.za; van Zyl, 2001), such as white pipe (Cannabis mixed with Mandrax and smoked in a broken-off bottleneck) (Peden et al., 2000), cremora (Cannabis sprinkled with finely ground Mandrax), double barrel (two crushed Mandrax tablets mixed with Cannabis) (SANCA, 2005: www.edoc.co.za). Mandrax is used in combination with Cannabis as Methaqualone tends to enhance the active ingredient in Cannabis, $\Delta^{9}$ - tetrahydrocannibinol (THC) (SANCA, 2005: www.edoc.co.za).

Little is known regarding the toxic effects of Mandrax as it was found to be a drug of little therapeutic value, due to its highly addictive effects that include physical and 
psychological dependence and rapid tolerance. Mandrax has become one of the drugs of choice amongst South African drug users (van Zyl, 2001) and has rapidly become the second most frequently abused illegal drug in South Africa, after Cannabis (Hicks et al., 1990, Kaplan and Sadock, 1997 and SANCA, 2005: www.edoc.co.za.). Abuse of Mandrax has increased the awareness of this drug; however, information about its toxicity is inadequate. In contrast the effects of Cannabis have been widely researched and have shown to have both contradictory toxic and therapeutic effects. Cannabis has shown to be a stressor for psychotic relapse in schizophrenia patients (Chopra and Smith, 1974 and Palsson et al., 1982), disrupts the ovulatory cycle (Hall and Solowij, 1998), decreases testosterone secretion and impairs sperm production (Dalterio et al., 1977). While in contrast is shown to relieve the symptoms of glaucoma (Hollister, 1986 and Robson, 2001) and migraines (Akerman et al., 2003), has a positive effect in diseases such as Multiple Sclerosis (Hollister, 1986, Robson, 2001 and Akerman et al., 2003), Parkinson's disease (Guzmán et al., 2002 and Croxford, 2003), anorexia associated with HIV/AIDS (Hollister, 1986 and Robson, 2001), Alzheimer's disease (Koo et al., 1999 and Iuvone et al., 2004) and lastly acts as a neuroprotective agent during ischaemia (Hampson et al., 2000).

Mandrax in combination with Cannabis is abused by all sectors of the population including pregnant woman, furthermore, the age of initiation is becoming younger. The developing brain of the foetus and young children is most vulnerable to the toxic effects of these drugs. Therefore, the aim of this study is to determine the effects of Mandrax and Cannabis alone and in combination on the developing brain by using primary and suspension cultures of the chick embryo brain.

\section{Materials and methods}

\subsection{Isolation of chick embryonic neuronal (CEN) cells}

Fertile chicken eggs were used for all the experiments and were obtained from National Chicks. Pty (Ltd.), and were stored at $4{ }^{\circ} \mathrm{C}$ for a maximum of 2 weeks. For the embryo to develop the fertile chicken eggs were then placed in the Grumbach incubator at a temperature $37.5^{\circ} \mathrm{C}$ until day of termination. All experiments conformed to the ethical 
considerations of the University of Pretoria and ethical clearance was obtained from the Ethical Committee of the University of Pretoria.

At E8 stage of development the broiler chick embryos were removed, decapitated and the brain vesicles (mostly the midbrain, mesencephalon) were removed and used to establish primary cultures of chick embryonic neurons (CEN). The tissue was cut into small fragments and washed with Hank's buffered saline solution (HBSS) (Highveld Biological Company, Johannesburg, South Africa) containing $3 \mathrm{~g} / 1$ bovine serum albumin (BSA) (Boehringer Mannheim, Randburg South Africa), (HBSS/BSA) to remove debris and blood cells before the tissue was incubated in $0.025 \%$ trypsin (Life Technologies Laboratory; supplied by Gibco BRL Products, Johannesburg, South Africa) prepared in HBSS/BSA for $15 \mathrm{~min}$ at $37^{\circ} \mathrm{C}$. Digestion was ended by adding and washing the cells thrice in Earle's essential medium (EMEM) containing 10\% foetal calf serum (FCS) and $1 \%$ antibiotic solution $(10,000 \mathrm{U} / \mathrm{ml}$ penicillin, $10,000 \mu \mathrm{g} / \mathrm{ml}$ streptomycin and $25 \mu \mathrm{g} / \mathrm{ml}$ amphotericin in $0.85 \%$ saline). A single cell suspension was obtained by mechanical trituration using a $5 \mathrm{ml}$ pipette (NUNC ${ }^{\mathrm{TM}}$ brand products, AEC-Amersham, Johannesburg, South Africa). The suspension was allowed to settle for 1-2 min and the cells suspended in the supernatant were collected by centrifugation and suspended in $10 \mathrm{ml}$ of EMEM containing 10\% FCS and antibiotics. These CEN cells are either plated to determine the effect of Mandrax and Cannabis on cell number following $24 \mathrm{~h}$ exposure or used as cell suspensions to determine the effects of these drugs on esterase activity after 1 and $4 \mathrm{~h}$ exposure.

To establish primary CEN cultures, the cells were plated at $37^{\circ} \mathrm{C}$ for $20-30 \mathrm{~min}$ onto the plastic surface of a $75 \mathrm{~cm}^{2}$ cell culture flask to allow the attachment of fibroblast and non-neuronal cells. The total cell count of non-attached CEN was performed using the Trypan Blue exclusion assay. CEN were re-plated onto the surface of poly-1-lysine coated ( $1 \mathrm{ml}$ poly-1-lysine (Sigma-Aldrich, Johannesburg South Africa) in $9 \mathrm{ml}$ sterile $\mathrm{ddH}_{2} \mathrm{O}$ ) well plates prepared as described by the manufactures. For each experiment, neuronal cells were plated at a cell concentration of $8 \times 10^{4}$ cells $/ \mathrm{ml}$ in 24 well plates with a culture area of $1.9 \mathrm{~cm}^{2} /$ well and were maintained at $37{ }^{\circ} \mathrm{C}$ and $5 \% \mathrm{CO}_{2}$ content for $48 \mathrm{~h}$ to allow optimal dendrite and axon development. The medium was not changed, as this causes dendrite and axon detachment. 


\subsection{Extracts of Mandrax and Cannabis}

Mandrax and Cannabis were obtained from the South African Forensic services and all clearances for use was obtained from the South African Police services via the legal department of the University of Pretoria.

The Mandrax was obtained in tablet form (as abused on the street) and a working solution of $10 \mathrm{mg} / \mathrm{ml}$ was prepared by dissolving $10 \mathrm{mg}$ Mandrax in $1 \mathrm{ml}$ of $70 \%$ ethanol. The concentration of the active ingredient MTQ was determined by GCMS and was $0.4335 \mathrm{mg} / \mathrm{g}$. Throughout all data will be reported as the amount of Mandrax added as the Mandrax purchased on the street may contain other toxic compounds that are added or formed during synthesis.

Cannabis was obtained in a dried leaf and seed form and in order to expose the cultures to this drug a water extract or a cannabis tea was prepared by boiling $0.01 \mathrm{~g}$ of dried Cannabis in $1 \mathrm{ml}$ of distilled $\mathrm{H}_{2} \mathrm{O}$ for $10 \mathrm{~min}$. The extract was filtered under sterile conditions and the concentration of plant material extracted was determined following freeze-drying and was $10 \mathrm{mg} / \mathrm{ml}$.

\subsection{Exposure of CEN primary cultures to Mandax and Cannabis alone and combination}

To CEN primary cultures a increasing concentrations of Mandrax $(0-0.5 \mathrm{mg} / \mathrm{ml})$ in volumes of $0,5,10,15,20$ and $25 \mu \mathrm{l}$ was added to a final volume of $500 \mu$ l. Primary cultures were also exposed to $0,10,20,40,80$ and $100 \mu l$ of the Cannabis water extract in $500 \mu \mathrm{l}$ medium giving a final concentration range of $0-2 \mathrm{mg} / \mathrm{ml}$. To study the effect of Mandrax and Cannabis in combination CEN cultures were exposed to $25 \mu$ ethanol (3.3\%, the concentration carrier used for the preparation of $0.5 \mathrm{mg} / \mathrm{ml}$ Mandrax) or $25 \mu 1$ $(0.5 \mathrm{mg} / \mathrm{ml})$ Mandrax in combination with increasing concentrations $0-2 \mathrm{mg} / \mathrm{ml}$ of Cannabis. After $24 \mathrm{~h}$ of drug exposure CEN cell number was determined using the Crystal Violet assay. At each exposure concentration each assay was done in quadruple and triplicate experiments were done. 


\subsection{Crystal Violet (CV) assay}

To determine CEN cell number, the cells were fixed by adding $100 \mu 1$ volume of $11 \%$ glutaraldehyde to the medium and shaking the plates for $30 \mathrm{~min}$ before being washed with water and dried overnight. The CEN cells were stained for $30 \mathrm{~min}$ by shaking. A $300 \mu \mathrm{l}$ volume of a $0.1 \%$ (weight/volume, w/v) Crystal Violet dye solution prepared in $200 \mathrm{mM}$ of formic acid pH 3.5 was used. After staining, the plates were washed with water, dried before the bound dye was extracted in $300 \mu$ of a $10 \%$ acetic acid solution. The dye solution was transferred to a 96 well plate and the absorbency at $595 \mathrm{~nm}$ was measured using a spectrophotometer (EL900) plate reader. Data were expressed as percentage of the control, CEN not exposed to ethanol, Mandrax or Cannabis.

\subsection{Exposure of CEN suspension cultures to Mandax and Cannabis alone and combination}

CEN suspensions were diluted to a final volume of $1 \times 10^{5}$ cells in $1 \mathrm{ml}$ of EMEM containing 10\% FCS and were exposed for 1 (T1) and 4 (T4) h to similar concentrations of Mandrax (0-60 $\mu 1,0-0.6 \mathrm{mg} / \mathrm{ml})$, ethanol (0-60 $\mu \mathrm{l}, 0-3.8 \%)$ and Cannabis $(0-$ $2 \mathrm{mg} / \mathrm{ml}$ ) as was used for primary $\mathrm{CEN}$ cultures at $37^{\circ} \mathrm{C}$. For combination studies at T1 and T4 CEN suspensions were exposed to $2 \mathrm{mg} / \mathrm{ml}$ of Cannabis in combination with increasing $(0,30,40$ and $60 \mu \mathrm{l} / \mathrm{ml})$ volumes of Mandrax, concentrations of $0-0.6 \mathrm{mg} / \mathrm{ml}$. Controls included cells not exposed to ethanol, Mandrax or Cannabis or exposed only to ethanol (3.3\%) Mandrax 0-0.6 mg/ml or $2 \mathrm{mg} / \mathrm{ml}$ Cannabis.

\subsection{Fluorescein diacetate (FDA) assay}

At T1 and T4 $500 \mu$ l of the cell suspension was collected by centrifugation, washed then suspended in $500 \mu \mathrm{l}$ DPBS to eliminate any fluorescence interference by medium, FCS, BSA or drugs. Fifty microlitres CEN suspension $\left(5 \times 10^{4}\right.$ cells $)$ was diluted 1:1 with DPBS, and $5 \mu \mathrm{l}$ of a $2 \mathrm{mM}$ FDA solution prepared in acetone was added. The fluorescence was measured at an excitation wavelength of $488 \mathrm{~nm}$ and an emission wavelength of $517 \mathrm{~nm}$, with a slit width of $2.5 \mathrm{~nm}$ at both wavelengths. The increase in fluorescence was measured over a time period of $20 \mathrm{~min}$ at 5 -min time intervals. The 
change in fluorescence over time was calculated and all data were reported as percentage relative to the control, not exposed to drug.

The FDA assay, autofluorescence values were always measured, and two controls were included in each experiment (i) positive control (not exposed to drug) and a (ii) negative control (dead cells, namely a cell suspension exposed to $100 \%$ ethanol for $15 \mathrm{~min}$ ).

\subsection{Statistical analysis}

The data were expressed as mean \pm standard error of mean (S.E.M.). One-way ANOVA and Tukey multiple comparison test was used to analyse data comparing controls and experimental groups. For pair wise, analysis the Dunnet multiple comparison test was used. Statistical analysis was performed using the Microsoft Exel, Analyse-it program.

\section{Results}

\subsection{The effect of Mandrax and Cannabis alone or in combination on CEN cell number}

For ethanol (Fig. 1A) and Cannabis (Fig. 1C), no significant decrease in cell number was observed. For Mandrax, a polynomial decrease $\left(r^{2}=0.94, p=0.0015\right)$ in cell number was observed from 100 to $68 \%$ for $0-0.5 \mathrm{mg} / \mathrm{ml}$ Mandrax added (Fig. 1B). A significant decrease in cell number was observed at the highest Mandrax concentrations of 0.4 and $0.5 \mathrm{mg} / \mathrm{ml}$ compared to control, no drug added. Comparison of CEN number between ethanol and Mandrax as well as Cannabis and Mandrax was significantly different with $p<0.0001$ for both. 

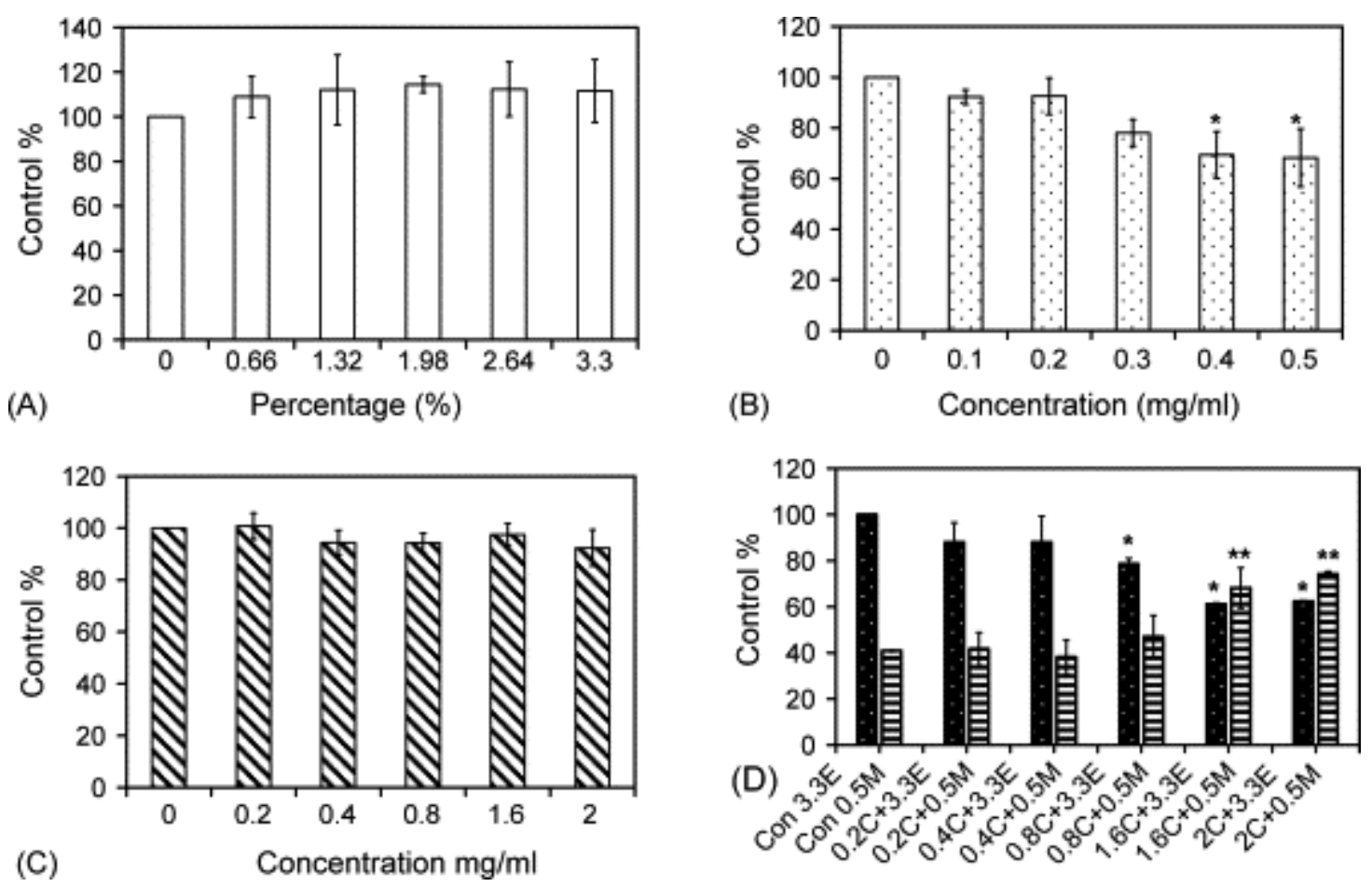

Fig. 1. Effects of increasing concentrations of: (A) ethanol (EtOH) (0-3.3\%), (B) Mandrax (M) (0-0.5 mg/ml), (C) Cannabis (C) (0-2 mg/ml) and (D) $\mathrm{M}$ and $\mathrm{C}$ in combination on cell number of CEN primary cultures. For (D) the controls are: Con 3.3E (only $3.3 \% \mathrm{EtOH})$, Con $0.5 \mathrm{M}(0.5 \mathrm{mg} / \mathrm{ml} \mathrm{M}$ prepared in $3.3 \% \mathrm{EtOH})$. Dotted bars are increasing concentrations of C $(0.2-2 \mathrm{mg} / \mathrm{ml})$ with $3.3 \mathrm{E}$. Striped bars are increasing concentrations of C with $0.5 \mathrm{M}$. (B) Asterisk (*) indicates significant decrease compared to control not exposed to Mandrax. (D) Asterisks (*) indicate significant decrease compared to Con $3.3 \mathrm{E}$ and $(* *)$ indicate significant increase compared to Con $0.5 \mathrm{M}$, $p \leq 0.05$ for $*$ and $* *$.

CEN were firstly exposed to increasing concentrations of Cannabis $(0-2 \mathrm{mg} / \mathrm{ml})$ in the presence of 3.3\% ethanol (carrier used for Mandrax) (Fig. 1D). A decrease was observed and was significant $\left(r^{2}=0.88\right)$, at $0.8 \mathrm{C}+3.3 \mathrm{E}, 1.6 \mathrm{C}+3.3 \mathrm{E}$ and $2 \mathrm{C}+3.3 \mathrm{E}(p=0.0060)$ compared to the control (Con 3.3E).

Mandrax alone (Con $0.5 \mathrm{M}$ ) induced a $60 \%$ decrease in cell number but in combination with increasing concentrations of Cannabis $(0-2 \mathrm{mg} / \mathrm{ml})$ a linear increase in cell number $\left(r^{2}=0.96, p=0.0006\right)$ was observed and was significant $(p=0.0062)$ at $1.6 \mathrm{C}+0.5 \mathrm{M}$ and $2 \mathrm{C}+0.5 \mathrm{M}$. 


\subsection{Effect of Mandrax and Cannabis either alone or in combination on CEN esterase activity}

Exposure to ethanol, led for T1 and T4 a polynomial decrease $\left(r^{2}=0.88, p=0.0052\right.$ and $\left.r^{2}=0.75, p=0.0266\right)$, (Fig. 2A and B) in esterase activity that was significant at 2.4 and $3.8 \%(p=0.0007$ and 0.0086$)$ added ethanol. For Mandrax at T1, a linear decrease $\left(r^{2}=0.98, p=0.0002\right)$ while at T4 a polynomial decrease $\left(r^{2}=0.92, p=0.02\right)$ in esterase activity was observed (Fig. 2C and D). This was significant for T1, at 0.3, 0.4, $0.6 \mathrm{mg} / \mathrm{ml}$ $(p=0.0029)$ and T4 at 0.4 and $0.6 \mathrm{mg} / \mathrm{ml}(p=0.002)$ Mandrax added. Pair wise comparison, at T1 (Fig. 2A versus C) and T4 (Fig. 2B versus D) between CEN exposed to $0-3.8 \%$ ethanol and $0-0.6 \mathrm{mg} / \mathrm{ml}$ Mandrax revealed no significant differences at $\mathrm{T} 1$ but differences were significant at T4 $(p=0.0096)$. CEN suspensions were exposed to increasing concentrations of the Cannabis extract for T1 and T4 were found to cause no significant changes in esterase activity (Fig. 2E and F). 

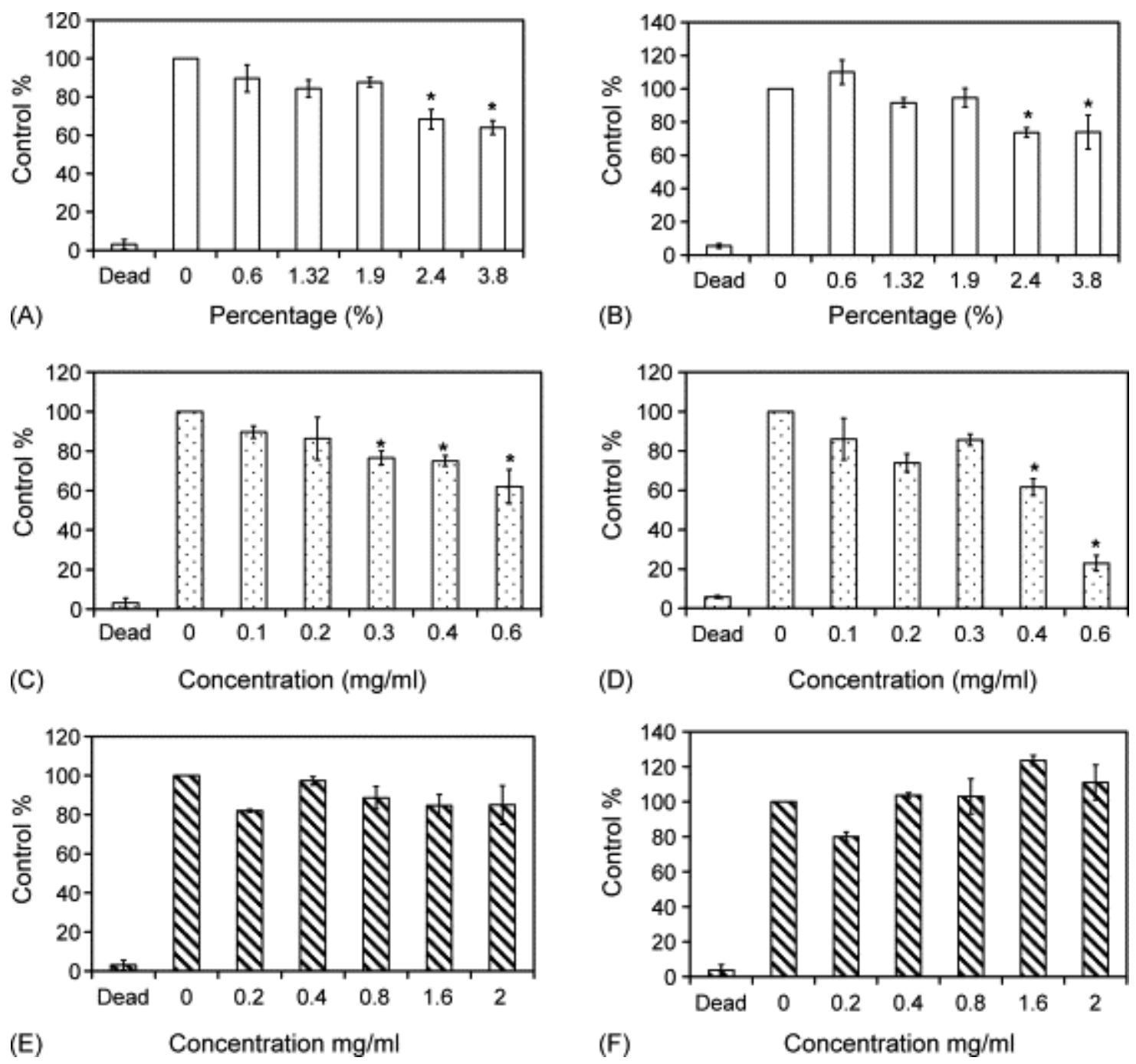

Fig. 2. Effects of increasing concentrations of (A and B) ethanol (0-3.8\%), (C and D) Mandrax $(0-0.6 \mathrm{mg} / \mathrm{ml})$ and $(\mathrm{E}$ and $\mathrm{F})$ Cannabis $(0-2 \mathrm{mg} / \mathrm{ml})$ esterase activity of CEN suspensions after 1 (A, C and E) and 4 (B, D and F) h measured using the FDA bioassay. Asterisk (*) indicates significant decrease in activity compared to control not exposed, $p \leq 0.05$.

The effects of Mandrax together with Cannabis showed at T1, $0.6 \mathrm{mg} / \mathrm{ml} \mathrm{Mandrax}$ $(0.6 \mathrm{M})$ alone and $0.6 \mathrm{M}$ in combination with $2 \mathrm{mg} / \mathrm{ml}$ Cannabis $(0.6 \mathrm{M}+2 \mathrm{C}) \mathrm{a}$ significant decrease in esterase activity when compared to the control with no drug added $(p=0.0055)$ (Fig. 3A). Mandrax reduces esterase activity to $45 \%$ while in combination with Cannabis esterase activity is reduced to $65 \%$ indicating that Cannabis causes a significant protective effect towards neurons that are exposed to $0.6 \mathrm{M}$. 

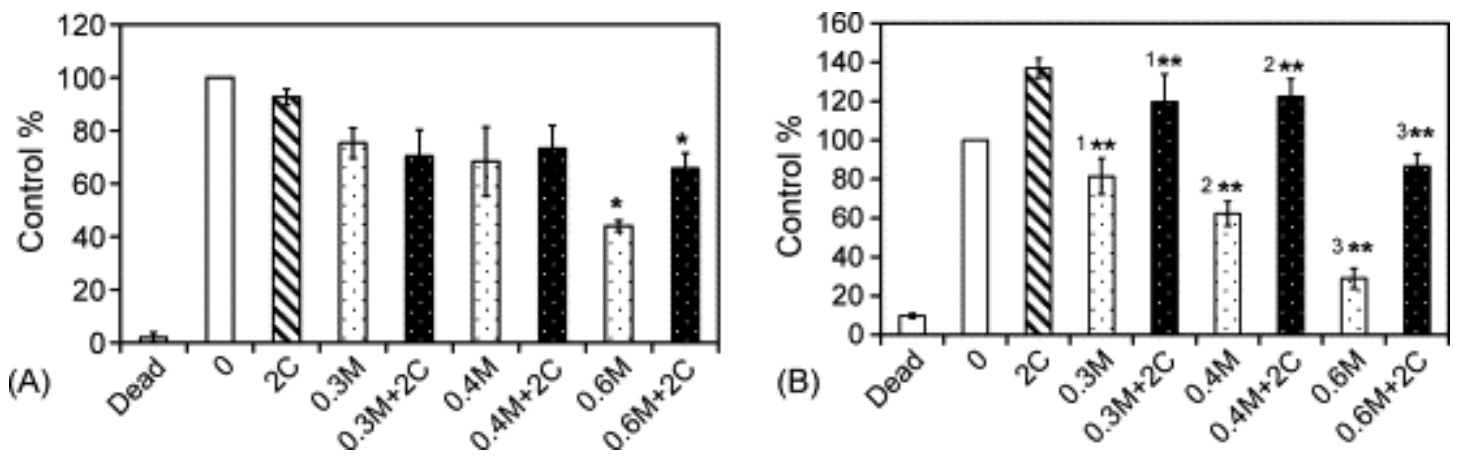

Fig. 3. The effects of combinations of Mandrax (M) and Cannabis (C) on esterase activity of CEN suspensions after exposure for (A) 1 and (B) $4 \mathrm{~h}$. Controls are dead (method control), 0 (not exposed to drug) and 2C (2 mg/ml Cannabis). CEN suspensions are exposed to $0.3 \mathrm{M}-0.6 \mathrm{M}(0.3-0.6 \mathrm{mg} / \mathrm{ml})$ and combinations $0.3 \mathrm{M}+2 \mathrm{C}(0.3 \mathrm{mg} / \mathrm{ml}$ $\mathrm{M}+2 \mathrm{mg} / \mathrm{ml} \mathrm{C})$ to $0.6 \mathrm{M}+2 \mathrm{C}(0.6 \mathrm{mg} / \mathrm{ml} \mathrm{M}+2 \mathrm{mg} / \mathrm{ml} \mathrm{C})$. (A) Asterisk (*) indicates significant decrease compared to control not exposed while $1^{* *}, 2^{* *}$ and $3^{* *}$ indicate a significant protective effect when $\mathrm{M}$ is compared to $\mathrm{M}+\mathrm{C}, p \leq 0.05$.

At T4 a significant decrease in esterase activity was observed for CEN exposed to Mandrax ( $p=0.0054)$ compared to control no drug added (Fig. 3B). The inclusion of $2 \mathrm{mg} / \mathrm{ml}$ Cannabis together with $0.3,0.4$ and $0.6 \mathrm{M}$ showed a significant increase in esterase activity when compared to individual controls $0.3,0.4$ and $0.6 \mathrm{M}$ again indicating a protective effect $(p=0.0022)$.

\section{Discussion}

The abuse of Cannabis and Mandrax is unique to South Africa, and the focus of research has been on the socio-economic impact rather than the adverse and possibly long-term effects on the developing brain of adolescence and the unborn (Fried, 2002). Drugs of abuse generally impact negatively on brain function and development and thus Mandrax and Cannabis toxicity was evaluated using a cell culture system of neurons that are embryonic in origin namely chick embryonic neurons (CEN). The effects of Mandrax and Cannabis alone and in combination were evaluated by measuring changes in cell number in primary cultures of CEN and esterase activity in cell suspensions of CEN. 
Methaqualone (2-methyl-3-o-tolyl-4(3H)-quinazolinone) (MTQ), found in Mandrax, was originally synthesised in India, tested and found to be ineffective as an anti-malaria drug. Later in 1959 due to its sedative effects, it was introduced in Great Britain as a prescription drug. However, it never sold well, subsequently Mandrax (250 mg Methaqualone and $25 \mathrm{mg}$ of antihistamine-diphenhydramine hydrochloride) (Ray, 1978 and van Zyl, 2001) was introduced pharmaceutically as a non-barbiturate, non-addictive sleeping pill (van Zyl, 2001), as a result of it having sedative and hypnotic properties as well as some anticonvulsant and antitussive actions (Bennett et al., 1983). Mandrax taken orally is absorbed rapidly in the gastrointestinal tract. For oral use, it is supplied in amounts of 75-300 mg as the free base and 200-400 $\mathrm{mg}$ as the hydrochloride. It has become a drug of abuse, being self-administered in oral doses of up to $3 \mathrm{~g}$ daily (San Diego reference laboratory: http://www.sdrl.com). Chronic usage can result in tolerance and physical dependence. Although Mandrax contains MTQ and diphenhydramine, the illicit product usually only contains MTQ as Hindmarsh et al. (1978) reported that diphenhydramine inhibits the metabolism of MTQ. Illicit synthesis of Mandrax/MTQ usually involves uncomplicated one or two-step reactions as described by van Zyl (2001) and therefore varies in MTQ content and contains contaminants derived from the synthesis process. In this study, Mandrax as abused was used rather than the pharmaceutical product or purified MTQ as the contaminants present may also contribute significantly to the toxicity of Mandrax, therefore Mandrax from a single source was used throughout this study. Likewise Cannabis may vary in Cannabinoid content according to the areas cultivated, time of harvesting and the harvesting process and therefore the same source of material was also used throughout this study (Maykut, 1985). Water extracts of Cannabis contains several active ingredients, the relative amounts of each, as well as the synergistic and additive toxic and neurophysiologic effects between compounds is not known. For this reason only the total amount of freeze-dried material was determined and all data were reported as such.

Shah et al., 1977, observed that orally administered MTQ in rats resulted in MTQ being uniformly distributed in various brain regions, due to the lipophilic nature of this drug (Shah et al., 1977 and Kuhn and Shah, 1978). Due to the high lipophilic nature of the myelin sheath, MTQ accumulates at this specific site, serving as a reservoir for MTQ 
with its eventual effect on the cells of the brain. Although little MTQ is found in the brain due to its high binding capacity to serum proteins, sufficient MTQ does reach the brain to induce behavioural and physiological effects (Morris et al., 1976) and therefore possible toxic effects (Kuhn and Shah, 1978). Besides these reported studies very little is known regarding the toxic effects of Mandrax and subsequently the focus of this study. In contrast to Mandrax the effects of Cannabis and its Cannabinoids have been widely researched and contradictive effects have been described for these compounds, with adverse effects being psychological and physiological dependence, and beneficial effects being therapeutic and neuroprotective (Solowij, 1998).

Primary neuronal cultures have been a popular research tool for decades as it allows easy access to individual neurons (Potter and DeMarse, 2001) and has been used to determine the neurotoxic or neuroprotective effects of a wide range of drugs (Richard et al., 1998). Neuronal tissue cultures, cultured from avian and mammalian central and peripheral nervous systems, provide an opportunity to study in situ properties of a wellcharacterised neuronal cell populations such as neurons, glial cells and astrocytes under relatively simple and carefully controlled conditions (Richard et al., 1998). Of these models, the chick embryo is still the most frequently used model and the advantage of this model is that the developmental events characterised by discrete transitions in behaviour of the embryo and chick has been well established (Rogers, 1995). The chick brain begins to differentiate as early as embryonic day (E) two (E2) of incubation (Rogers, 1995), and according to Hamburger and Hamilton stages of chick embryo development the three primary brain vesicles develop during the 33rd to the 38 th hour after incubation (Hamburger and Hamilton, 1951). Neurogenesis begins at E2 of incubation and reaches a peak at E8 of development; and therefore primary cultures established at this stage of development will contain cells where neurotransmission systems are still developing (Kentroti and Vernadakis, 1997) and are at this stage possibly the most sensitive to the neurotoxic effects of drugs. Isolated CEN cells rapidly attached to form a well-developed neuronal network associated with stage IV of neuron development in vitro as described by Doti et al. (1988) and Bradke and Doti (2000). All experiments were completed within $72 \mathrm{~h}$ to ensure that the distribution of the different cell populations closely resembles that of the chick brain and to ensure that no single cell 
population had sufficient time for overgrowth as has been described for astrocytes. For CEN cells exposed to Mandrax a dose dependent decrease in cell number was observed while no effect was observed for ethanol (carrier) and Cannabis. The absence of an effect for Cannabis was either that the concentration of the extracted Cannabinoids was too low or that the Cannabinoids extracts using this method do not contain all the smoke derived components found in cigarettes prepared using Cannabis. Hampson et al. (2000) observed that Cannabinoids were not toxic but did have an anti-oxidative effect on rat cortical neuronal cells in vitro. In this study, Mandrax alone is toxic but in combination with increasing concentrations of Cannabis a linear increase in cell number was observed. When Cannabis is added together with ethanol a toxic effect is observed. This however was not the focus of this study and the effect observed deserves further investigation. Except for astrocytes most of the cells in CEN primary culture undergo differentiation rather than proliferation. Therefore, rather than Cannabis having a mitogenic effect resulting in an increase in cell number it is protecting the neuronal cells from the toxic effects of Mandrax. To confirm these effects and to ensure that changes in cell number are not contributing to these effects. These studies were repeated using suspensions of CEN cells and the FDA bioassay that measures changes in intracellular esterase activity. Exposure of CEN suspensions to ethanol, Mandrax and Cannabis resulted in a time and dose response effect for ethanol and Mandrax but not for Cannabis. At the highest concentration of Cannabis an increasing concentration of Mandrax was added. Between group comparisons revealed that Cannabis protected the neurons from the toxic effects of Mandrax. Hampson et al. (2000) reported that Cannabidiol and other Canabinoids had a neuroprotective effect based on the anti-oxidative effect of these compounds. Cannabidiol was reported to be a more powerful antioxidant than $\alpha$-tocopherol and ascorbic acid. A study by Iuvone et al. (2004), using rat pheocromocytoma PC12 reported that Cannabidiol prior to $\beta$-amyloid peptide exposure decreased lipid peroxidation, ROS production, caspase 3 levels and DNA fragmentation. The protective effect observed in this study may be consequence of the manner in which the Cannabis extracts are prepared. Further investigations should be undertaken using smoke extracts as smoking of a mixture of Mandrax and Cannabis is the most common form of abuse. A study by Sarafian et al. (2002) achieved, tar-containing extracts from tobacco or marijuana smoke 
by passing whole smoke from a single cigarette through a Cambridge filter. Filters were then thoroughly dried, weighed and then extracted with DMSO. Alternative protocols used for in vitro studies, included bubbling cigarette smoke directly into buffered saline or DMEM (Yamaguchi et al., 2004) while other studies have used modifications of a number of existing methods (Mazzio et al., 2005). Sarafian et al. (2001) observed, following exposure of A549 lung tumour cells to Cannabis smoke that ATP levels were reduced, which is consistent with toxic effects on mitochondrial electron transport and therefore similar studies may yet show that Mandrax and Cannabis in combination may have increased cytotoxic effects.

In conclusion, this is the first study that shows that Mandrax is toxic and causes decrease in cell number and esterase activity in CEN cell cultures and suspensions. Furthermore, toxicity was also found in neuronal suspension cultures when esterase activity was measured. In contrast Cannabis exhibited no toxic effects on the CEN cell cultures and in neuronal cell suspensions. In combination with Mandrax a neuroprotective effect was observed in primary neuronal cultures and this effect was confirmed when esterase activity was measure in neuronal suspension cultures. However, the effect of Cannabis smoke still needs to be investigated as this may cause a synergistic or additive toxicity of Mandrax.

\section{References}

Akerman et al., 2003 S. Akerman, H. Kaube and J. Goadsby, Anandamide is able to inhibit trigeminal neurons using an in vivo model of trigeminovascular-mediated nociception, J. Pharmacol. Exp. Ther. 309 (2003) (1), pp. 56-63.

Bennett et al., 1983 G. Bennett, C. Vourakis and D.S. Woolf, Substance AbusePharmacological, Developmental and Clinical Perspectives, John Wiley and Sons, Inc., New York (1983).

Bradke and Doti, 2000 F. Bradke and C.G. Doti, Establishment of neuronal polarity: lessons from cultured hippocampal neurons, Curr. Opin. Neurobiol. 10 (2000), pp. 574 581.

Chopra and Smith, 1974 G.S. Chopra and J.W. Smith, Psychotic reactions following cannabis use in east Indians, Arch. En. Psychiatry 30 (1974), pp. 24-27. 
Croxford, 2003 J.L. Croxford, Therapeutic potential of cannabinoids in CNS disease, CNS Drugs 17 (2003) (3), pp. 179-202.

Dalterio et al., 1977 S. Dalterio, A. Bartke and S. Burstein, Cannabinoids inhibit testosterone secretion by mouse testes in vitro, Science 196 (1977) (4297), pp. 14721473.

Doti et al., 1988 C.G. Doti, C.A. Sullivan and G. Banker, The establishment of polarity by hippocampal neurons in culture, J. Neurosci. 8 (1988), pp. 1454-1468.

Fried, 2002 P.A. Fried, Conceptual issues in behavioural teratology and their application in determining long-term sequelae of prenatal marihuana exposure, J. Child Psychol. Psychiatry 43 (2002) (1), pp. 81-102.

Guzmán et al., 2002 M. Guzmán, C. Sánchez and I. Galve-Roperh, Cannabinoids and cell fate, Pharmacol. Ther. 95 (2002) (2), pp. 175-184.

Hall and Solowij, 1998 W. Hall and N. Solowij, Adverse effects of cannabis, Lancet North Am. Ed. 352 (1998) (9140), pp. 1611-1616.

Hamburger and Hamilton, 1951 V. Hamburger and H. Hamilton, Series of embryonic chicken growth, J. Morphol. 88 (1951), pp. 49-92.

Hampson et al., 2000 A.J. Hampson, M. Grimaldi, M. Lolic, D. Wink, R. Rosenthal and J. Axelrod, Neuroprotective antioxidants from marijuana, Ann. N.Y. Acad. Sci. 899 (2000), pp. 274-282. View Record in Scopus | Cited By in Scopus Hicks et al., 1990 T.P. Hicks, T. Kaneko and J.I. Oka, Receptive-field size of S1 cortical neurons is altered by Methaqualone via a GABA mechanism, Can. J. Neurol. Sci. 17 (1990) (1), pp. 30-34.

Hindmarsh et al., 1978 K.W. Hindmarsh, N.W. Hamon, D.F. LeGatt and S.M. Wallace, Effect of diphenhydramine on methaqualone metabolism: an in vitro study, J. Pharm. Sci. 67 (1978), pp. 1547-1557.

Hollister, 1986 L.E. Hollister, Health aspects of cannabis, Pharmacol. Rev. 38 (1986) (1), pp. 1-20.

Iuvone et al., 2004 T. Iuvone, G. Esposito, R. Esposito, R. Santamaria, M. Di Rosa and A.A. Izzo, Neuroprotective effect of cannabidiol, a non-psychoactive component from Cannabis sativa, on $\beta$-amyloid-induced toxicity in PC12 cells, J. Neurochem. 89 (2004), pp. 134-141. 
Kaplan and Sadock, 1997 H.I. Kaplan and B.J. Sadock, Synopsis of Psychiatry:

Behavioural Sciences/Clinical Psychiatry, Williams and Wilkins, Baltimore (1997).

Kentroti and Vernadakis, 1997 S. Kentroti and A. Vernadakis, Differential Expression in glial cells derived from chick embryo cerebral hemispheres at an advanced stage of development, J. Neurosci. Res. 47 (1997), pp. 322-331.

Koo et al., 1999 E.H. Koo, P.T. Lansbury and J.W. Kelly, Amyloid diseases: abnormal protein aggregation in neurodegeneration, Proc. Natl. Acad. U.S.A. 96 (1999), pp. 99899990.

Kuhn and Shah, 1978 D.M. Kuhn and N.S. Shah, Subcellular localization of $\left[{ }^{14} \mathrm{C}\right]$ methaqualone in mouse brain: effects of hepatic microsomal enzyme inhibition, Toxicol. Appl. Pharmacol. 46 (1978), pp. 109-116.

Maykut, 1985 M.O. Maykut, Health consequences of acute and chronic marijuana use, Prog. Neuropsychopharmacol. Biol. Psychiatry 9 (1985), pp. 209-238.

Mazzio et al., 2005 E.A. Mazzio, M.G. Kolta, R.R. Reams and K.F.A. Soliman, Inhibitory effects of cigarette smoke on glial inducible nitric oxide synthase and lack of protective properties against oxidative neurotoxins in vitro, Neurotoxicology 26 (2005), pp. 49-62.

Medical Research Council, 2000 Medical Research Council, 2000. South African Community Epidemiology Network on Drug Use (SACENDU), Proceedings of the Report Back Meetings, July-December 1999, Phase 7. www.mrc.co.za, 2 February 2006. Morris et al., 1976 R.N. Morris, G.A. Gunderson, T. Herczeg and N.H. Reavey-Cantwell, Plasma levels and absorption of methaqualone after oral administration to man, Clin.

Pharmacol. Ther. 13 (1976), pp. 719-723.

Palsson et al., 1982 A. Palsson, S.O. Thulin and K. Tunving, Cannabis psychosis in south Sweden, Acta Psychiatr. Scand. 66 (1982), pp. 311-321.

Peden et al., 2000 M. Peden, J. van der Spuy, P. Smith and P. Bautz, Substance abuse and trauma in Cape Town, S. Afr. Med. J. 90 (2000) (3), pp. 251-255.

Potter and DeMarse, 2001 S.M. Potter and T.B. DeMarse, A new approach to neural cell culture for long-term studies, J. Neurosci. Methods 110 (2001) (1-2), pp. 17-24. Ray, 1978 O. Ray, Drugs, Society, and Human Behaviour, The C.V. Mosby Company, Saint Louis (1978). 
Richard et al., 1998 O. Richard, A.H. Duittoz and T.K. Hevor, Early, middle, and late stages of neural cells from ovine embryo in primary cultures, Neurosci. Res. 31 (1998) (1), pp. 61-68.

Robson, 2001 P. Robson, Therapeutic aspects of cannabis and cannabinoids, Br. J. Psychiatry 178 (2001), pp. 107-115.

Rogers, 1995 L.J. Rogers, The Development of Brain and Behaviour in the Chicken, CAB International, Wallingford (1995).

SANCA, 2005 SA National Council on Alcoholism and Drug Dependence (SANCA), 2 March 2005. www.edoc.co.za, 2 February 2006.

Sarafian et al., 2002 T.A. Sarafian, S. Kouyoumjian, D. Tashkin and M.D. Roth, Synergistic cytotoxicity of delta-9-tetrahydrocannabinol and butylated hydroxyanisole, Toxicol. Lett. 133 (2002), pp. 171-179.

Sarafian et al., 2001 T.A. Sarafian, D.P. Tashkin and M.D. Roth, Marijauana smoke and delta-9-tetrahydrocannabinol promote necrotic cell death but inhibit fas-mediated apoptosis, Toxicol. Appl. Pharmacol. 174 (2001), pp. 264-272.

Shah et al., 1977 N.S. Shah, E. Hixson, O.D. Gulati, D. Kuhn and P.P. Mathur, Maternalfetal distribution of methaqualone in control and SKF 525-A-pretreated pregnant mice, Toxicol. Appl. Pharmacol. 40 (1977), pp. 497-509.

Solowij, 1998 N. Solowij, Cannabis and Cognitive Functioning. International Research Monographs in the Addictions (IRMA), Cambridge University Press, Cambridge (1998). van Zyl, 2001 E.F. van Zyl, A survey of reported synthesis of methaqualone and some positional and structural isomers, Forensic Sci. Int. 122 (2001), pp. 142-149. Yamaguchi et al., 2004 Y. Yamaguchi, S. Matsuno, S. Kagota, J. Haginaka and M. Kunitomo, Peroxynitrite-mediated oxidative modification of low-density lipoprotein by aqueous extracts of cigarette smoke and the preventive effect of fluvastatin, Arteriosclerosis 172 (2004), pp. 259-265.

Corresponding author. Tel.: +27 12 3192533; fax: +27 123192240 . 